\title{
Nilai Kearifan Lokal Bugis sebagai Sumber Belajar Sejarah Lokal pada Masyarakat Bugis di Kabupaten Bone
}

\author{
Khaeruddin, Umasih, Nurzengky Ibrahim \\ Fakultas Ilmu Sosial, Universitas Negeri Makassar \\ Email: khaeruddinfis@unm.ac.id, umasih@unj.ac.id, nurzengky@unj.ac.id
}

\begin{abstract}
This study aims to determine the understanding of Bugis local wisdom conception in the life of Bone district community and to know the application of local wisdom values to Bugis society through Bugis School. The research method used is qualitative research with data collection method done by observation, interview, literature study. The results of this study indicate that the Bugis local wisdom values in the form of literature and history contained pappaseng (ancestral messages) which included ada'tongeng (truth-telling), lempu (honest), getteng (steely stance), sipakatau (mutual respect) sipakalebbi (mutual exaltation), assitinajang (kepatutan) and mappesonae ri Dewata Seuwwae (surrendered to God) serve as a source of learning local history. the values of local wisdom are understood as belonging to the Bone community and studied together through the Bugis school as a guide in attitude and action. Likewise also with historical events that occur in the community Bone contains pappaseng both implicitly and explicitly then reviewed and used as a source of learning local history.
\end{abstract}

Keyword: Bugis local wisdom, learning resources, local history, Bone Society

\begin{abstract}
Abstrak: Penelitian ini bertujuan untuk mengetahui pemahaman konsepsi kearifan lokal Bugis dalam kehidupan masyarakat kabupaten Bone dan mengetahui penerapan nilainilai kearifan lokal pada masyarakat Bugis melalui Sekolah Bugis. Metode penelitian yang digunakan merupakan penelitian kualitatif dengan metode pengumpulan data dilakukan dengan cara observasi, wawancara, studi pustaka. Hasil penelitian menunjukkan bahwa nilai kearifan lokal Bugis yang berupa sastra dan sejarah yang didalamnya mengandung pappaseng (pesan-pesan leluhur) yang mencakup ada' tongeng (berkata benar), lempu (jujur), getteng (teguh pendirian), sipakatau (saling menghormati), sipakalebbi (saling memuliakan), assitinajang (kepatutan) dan mappesonae ri Dewata Seuwwae (berserah diri kepada Tuhan) dijadikan sebagai sumber belajar sejarah lokal. Nilai-nilai kearifan lokal tersebut dipahami sebagai milik bersama masyarakat Bone dan dipelajari bersama melalui sekolah Bugis sebagai pedoman dalam sikap dan bertindak. Begitupun juga dengan peristiwa-peristiwa sejarah yang terjadi dimasyarakat Bone mengandung pappaseng baik secara tersirat dan tersurat yang kemudian ditelaah dan dijadikan sumber belajar sejarah lokal.
\end{abstract}

Kata kunci: Kearifan lokal Bugis, sumber belajar, sejarah lokal, Masyarakat Bone. 


\section{PENDAHULUAN}

Bangsa Indonesia adalah sekumpulan masyarakat yang berasal dari beragam latar belakang etnik sosio-kultural, sosio-histori, dan etnogeografi. Ibarat Indonesia sekarang adalah hasil peleburan dari rupa budaya dan wilayah. Sejarah mencatat bahwa ada sekitar ratusan kerajaan yang pernah eksis di nusantara ini. pada masyarakat Bugis terdapat kerajaan Bone, Kerajaan Soppeng. Pada masyarakat Makassar terdapat Kerajaan Gowa-Tallo, dan etnis-etnis lain dengan institusi politiknya masing-masing. Kendati demikian dari sekian banyaknya kesatuankelokalan masing-masing etnis justru menjadi rajutan yang mengokohkan penyatuan nasional. Puncaknya, tahun 1945 menjadi momentum penyatuan dan peleburan dari peralihan kelokalan menjadi me-nasional, menjadi bangsa Indonesia. Kendati penyatuan yang dimaksud bukan berarti menghilangkan nilai dan warna dari unsur-unsur kelokalan tersebut.

Ciri kultural tetap ada, bahkan menjadi identitas unik dari kelokalannya. Dari beragam etnis tersebut, mewakili ciri kulturalnya masing-masing, ciri kultural dengan kearifan lokalnya. kearifan lokal tersebut sebagai representasi identitas kelokalan dari suatu etnik masyarakat, baik itu yang mencakup adat istiadat, bahasa dan peristiwa kelampauan. Sulawesi Selatan yang merupakan salah satu provinsi di Indonesia, yang didiami oleh etnik Bugis, Makassar, Kajang dan Toraja, kaya akan nilai-nilai kearifan lokal yang telah mentradisi dan dijadikan pedoman bagi masyarakatnya. Etnik Bugis sebagai salah satu etnik terbesar di wilayah ini, salah satunya mendiami wilayah Kabupaten Bone. 
Identitas ke-Bugis-an seseorang tidak hanya karena ditentukan oleh faktor biologisnya, tetapi juga yang tak kalah pentingnya adalah faktor ideologis Nilai-nilai pembentuk dan pengikat masyarakat Bugis yang berupa adat istiadat / pangadderang, sastra yang sarat pesan dan nasihat dan sejarah menjadi pedoman bersikap dan bertindak, menjadi ideologi hidup. Apalah jadinya, jikalau secara biologis mengaku sebagai masyarakat Bugis namun ideologi hidupnya, yang menjadi tolak ukur sikap dan tindaknya tidak mencerminkan masyarakat Bugis. Hal ini kemudian penting ditekankan bahwa, baik secara biologis dan ideologis, keduanya harus seiring sejalan. Olehnya itu, sedari dini penanaman dan pewarisan nilai-nilai kearifan lokal Bugis harus semakin dimatangmantapkan. Pewarisan nilai-nilai kearifan lokal melibatkan tiga komponen, baik itu melalui lingkungan keluarga, pendidikan dan lingkungan sosial kemasyarakatan.

Pendidikan sebagai mekanisme sistemik dan sistematis, baik itu pendidikan formal dan non formal memiliki andil yang sangat tepat menjadi wadah internalisasi nilai-nilai kearifan lokal, kendati tanpa menafikkan peranan keluarga dan lingkungan sosial sekelilingnya. Namun disadari pula, bahwa terrnyata pendidikan formal yang diatur dalam Undang-Undang, baik tingkat SD, SMP, dan SMA mata pelajaran yang diajarkan tidak memberikan porsi yang cukup signifikan dalam penanaman nilai-nilai kearifan lokal Bugis tersebut. Olehnya itu kemudian jalur non formal menjadi alternatif utama pewarisan nilai kearifan lokal Bugis. Di Kabupaten Bone, Sekolah Bugis, sebagai lembaga pendidikan non formal menjadi wadah implementasi penyaluran nilai- 
nilai kearifan lokal sebagai bagian materi sumber belajar sejarah lokal dan pendidikan karakter terhadap masyarakat Bugis di Kabupaten Bone.

\section{METODE}

Penelitian ini merupakan penelitian kualitatif. Metode yang digunakan untuk memperoleh data tentang setting sosial, pemikiran dan kajian kearifan lokal yang terkandung dalam sastra dan sejarah lokal yang relevan untuk kemudian dijadikan sumber belajar sejarah lokal dan pendidikan karakter pada masyarakat Bone melalui sekolah Bugis. Penelitian kualitatif adalah metode penelitian yang berdasarkan pada filsafat postpositivisme yang biasanya digunakan untuk meneliti pada kondisi objektif yang alamiah dimana peneliti berperan sebagai instrumen kunci. (Sugiyono:2008). Dengan melakukan prosedur penelitian yakni, identifikasi masalah, review informasi, pengumpulan data yang berkaitan dengan topik penelitian, analisis data yang telah dikumpulkan dan terakhir Penarikan kesimpulan(Emzir:2015). Hal ini dilakukan guna mendapatkan hasil penelitian secara objektif. Adapun proses pengumpulan data dilakukan dengan cara observasi, wawancara, dan

studi pustaka. Observasi dilakukan bukan hanya di Sekolah Bugis dan lokasi diklat sekolah Bugis tetapi juga melihat aktivitas kehidupan masyarakat Bugis, terutama masyarakat yang hidup di Kab.Bone dan sekitarnya sementara wawancara dilakukan kepada semua subjek yang terkait dalam penelitian ini yaitu tokoh masyarakat, pengajar, budayawan dan peserta didik.

\section{HASIL DAN PEMBAHASAN}




\section{Pemahaman Konsepsi Kearifan Lokal Bugis dalam Kehidupan Masyarakat Bone}

Berdirinya Bone sebagai suatu wilayah yang berdaulat bersamaan dengan nilai-nilai yang mengikat bagi masyarakatnya. Nilai-nilai tersebut menjadi ideologi yang mengatur dan menjadi milik dan ingatan bersama oleh masyarakat Bone yang kemudian menjadi kearifan lokalnya. Salah satu nilai-nilai yang kemudian menjadi penciri khas bagi masyarakat Bugis Bone adalah sastra dan sejarah. Sastra dan sejarah Bone tersebut menjadi bukti eksistensi masyarakat Bugis Bone dari zaman ke zaman. Sebagai suatu "ideologi" bersama, maka pemahaman konsepsi sastra dan sejarah Bugis sebagai suatu kearifan lokal, secara garis besar telah banyak diketahui oleh masyarakat Bone. Dalam konteks penelitian ini, para peserta sekolah Bugis sebagai representasi masyarakat Bone mayoritas telah mengetahui kearifan lokal tersebut. Seperti diungkapkan Supriadi, bahwa nilai kearifan bahwa Bugis mempunyai nilai karakter, nilai budaya yang sangat baik dalam berbuat, bertutur kata, dan selalu menjunjung tinggi adatnya. Supiati juga mengatakan bahwa nilai kearifan lokal tersebut berupa, paseng toriolo (pesan leluhur) pammali (pantangan / larangan), elong kelong (nyanyian), sejarah tana' Bone. Hal ini menandakan bahwa, baik paseng/pappangaja, pammali, elong kelong dan sejarah telah mereka pahami sebagai suatu milik bersama yang mereka dapat dari tuturan orang tua dalam keluarganya dan dari pihak tetua masyarakat di desanya.

Begitupula yang diungkapkan oleh Aisyah, yang membagi nilai kearifan lokal Bugis dari dua hal yakni segi bahasa dan sosial, "dari segi bahasa, orang Bugis tutur bahasanya lemah lembut dalam berbicara, dan dari segi sosial, masyarakat Bugis masih mengedepankan sistem gotong 
royong dan kekeluargaan. Hal ini dapat dijumpai dalam kehidupan sehari-hari masyarakat Bone dalam berucap misalnya, menggunakan kata "iye" sebagai bentuk kesopanan dibanding menggunakan kata "iyo", begitupun aturan "mappatabe" suatu bentuk penghormatan orang muda kepada orang yang lebih tua, atau masyarakat biasa kepada tokoh masyarakat. Begitupun dalam kehidupan sehari-hari, kegotong-royongan masih kental, misalnya dalam proses pembangunan rumah, acara-acara mappabotting (pernikahan), acara-acara syukuran dan bakti sosial. Mereka saling membantu, dan merasa bahwa acara satu orang merupakan acara bersama. Begitupula dengan ikatan kekerabatan bagi masyarakat Bugis begitu kuat, dalam ikatan keluarga yang satu darah memiliki rasa siri dan pesse yang harus dijaga satu sama lain.

\section{Sastra dan Sejarah sebagai Sumber Belajar Bagi Masyarakat Bone Melalui Sekolah Bugis}

Sastra dan sejarah lokal Bugis merupakan akumulasi sikap dan tindak yang tercakup dalam tradisi lisan dan aktivitas kelampauannya. Sastra Bugis termuat pappaseng (petuah dan nasihat) yang dituturkan secara turun temurun, dalam lingkungan keluarga dan masyarakat. Selain sebagai petuah dan nasihat, pappaseng bagi orang Bugis juga disebut warisan paddisengeng (ilmu pengetahuan) yang juga mengandung muatan hukum dan agama yang dinafasi oleh perasaan siri' (Ningsih:2015). Mereka memahami bahwa, pappaseng itu akan membentuk nilai karakter/jati diri Bugis yang sesungguhnya. Bahwa masyarakat Bone dalam bertutur kata harus baik, halus, dan sopan. Mereka memahami bahwa, tradisi lisan yang berwujud sastra Bugis baik dalam bentuk nyanyian, syair, sajak, peristiwa masa lalu, dan ungkapanungkapan bijak dari pendahulu-pendahulunya dari segi bahasa sangat 
indah, dilafalkan dengan merdu dan menarik, namun yang tak kalah pentingnya, adalah unsur maknawi didalamnya. Nilai maknawi tersebutlah inti dari ungkapan-ungkapan indah tersebut.

Semisalnya, pappaseng Bugis dalam lontara, Tellui somperenna lino: “Lempuu, Getteng, Ada Tongeng na Appasikua. Narimakkuannanaro aaja' laalo musaala panguju, aja'to mutettangngi sempajangmu, aja'laalo mucapa-capai pappasekku, nasaba' anu maddupa tu matti. (artinya: Ada tiga hal yang menjadi kiat utama merantau (hidup) didunia yakni; Kejujuran, Keteguhan hati, tutur kata yang berlandaskan kebenaran, dan keikhlasan menerima apa adanya. Oleh sebab itu, janganlah kamu salah rencana dan salah melangkah, dan juga janganlah kamu pernah meninggalkan sembahyang lima waktu, serta janganlah kamu memandang remeh petuah ini, karena itu mengandung kebenaran yang akan menjadi kenyataan kelak).

Dari pappaseng tersebut diatas, dipahami bahwa, dunia adalah tempat merantau, dalam perantauan tersebut haruslah berpegang pada tiga hal yakni, kejujuran, keteguhan hati, dan tutur kata yang berlandaskan kebenaran dan keikhlasan. Dalam menjalani kehidupan dunia maka kita harus berpedoman pada tiga hal tersebut dan juga menegakkan shalat lima waktu.

Dalam pappaseng lainnya diungkapkan, Limai uwangenna riallolongengi deceng, seuwani pakatunai alemu risilasannae, maduanna saroko maserisilasannae, matellunna makkareso patujue, maeppa'na moloie roppo roppo narewe', malimanna molae laleng namatike' nappa sanre' ri Allah SWT. (Artinya : Lima jenis sifat manusia menghasilkan kebaikan, pertama merendahkan diri sepatutnya, kedua mencari kawan/sahabat sepatutnya, ketiga berbuat/bekerja 
yang baik dan benar, ke empat kembali apabila menghadapi rintangan, kelima waspada dalam perjalanan sambil berserah diri kepada Allah SWT).

Bahwa ada lima hal yang mengantarkan manusia untuk mendapatkan kebaikan yakni: merendahkan diri, berteman dengan orang yang baik, bekerja dengan baik dan benar, tidak mengambil jalan yang merusak diri dan terakhir senantiasa berhati-hati dan tawakkal kepada Allah SWT. Dua pesan tersebut diatas memberikan pemahaman kepada peserta sekolah Bugis untuk bagaimana bersikap dan berprilaku. Mereka mengetahui isi pappaseng tersebut dan mereka memahami bahwa isi dari pappaseng tersebut adalah modal utama dalam kehidupan sehari-hari, oleh orang Bugis disebut sebagai bokong temmaawari' (bekal abadi untuk hari akhir).

Begitupun halnya, bahwa peristiwa kelampauan (sejarah) yang terjadi di Bone dan masyarakat Bugis, baik yang dituturkan secara lisan dan dibukukan dalam lontara juga memiliki nilai maknawi. Peristiwa sejarah yang terjadi pada Kerajaan Bone dan masyarat Bugis zaman dahulu, mengantarkan generasi sekarang untuk mengetahui dan memahami. Dengan mengetahui, masyarakat Bone sadar bahwa sejarah masa lalunya harus digali, dan dilestarikan, mereka sadar dengan mengetahui sejarahnya, mereka mengetahui asal-usulnya, dinamika yang terjadi dalam kelokalannya dan mengetahui keeksistensian komunitasnya. Dengan memahami, masyarakat Bone dituntut untuk mengambil hikmah didalamnya, peristiwa perang masa lalu akibat karena kecerobohan, keegoisan, dan keserakahan telah menghantarkan pada kehancuran. Dengan demikian, seharusnya menghindari diri dari sifat-sifat tersebut. 
Dengan mempelajari sejarah Bone dan riwayat raja-rajanya, peserta Sekolah Bugis dapat membandingkan pemerintahan Raja Bone ke 8, La Inca dan Raja Bone ke 15, Latenritatta Arung Palakka. La Inca yang hanya memenuhi nafsu dan hasrat pribadinya, merugikan diri sendiri dan Tana' Bone, La Inca telah melanggar pangaddereng (adat istiadat) dan tidak mengindahkan pappaseng dan pappangaja maka dia dihukum mati. Berbeda dengan Arung Palakka, dimana dianggap sebagai putra Bone dengan didorong oleh siri' dan pesse'nya terpanggil untuk memerdekakan negerinya dari penjajahan, membebaskan penderitaan rakyatnya dan menegakkan asas assitinajang, kapatutan dan kepantasan sebagaimana diatur dalam pangaddereng. Mempelajari riwayat dua penguasa yang kontadiktif tersebut, mengantarkan peserta Sekolah Bugis untuk memahami dan mengambil pelajaran yang berharga, yang menuntut untuk bersikap pada dua hal, mengabaikan pappaseng dan pangaddereng dan atau mematuhi dan menjunjung pappaseng dan pangaddereng. Dalam peristiwa sejarah ini tampak dengan jelas bahwa, peserta sekolah Bugis, dituntut untuk mengetahui dan memahami serta mengimplementasikan dalam kehidupan sehari-harinya.

Kearifan Lokal Bugis; Tinjauan dalam Pendidikan Karakter dan Sumber belajar Sejarah Lokal

Memahami pendidikan karakter maka harus memahami konsepsi pendidikan dan karakter itu sendiri. Pendidikan merupakan suatu proses dimana suatu bangsa mempersiapkan generasi mudanya untuk menjalankan kehidupan dan untuk memenuhi tujuan hidup secara efektif dan efisien (Azra:2014) Sementara pengertian karakter menurut Wynne dibagi atas dua. Pertama, menunjukkan bagaimana seseorang bertingkah 
laku. Jika seseorang berprilaku tidak jujur, kejam, rakus maka tentunya orang tersebut memanifestasikan perilaku buruk. Begitupun sebaliknya, seseorang yang berprilaku jujur, suka menolong dan sikap baik lainnya tentulah orang tersebut memanifestasikan karakter mulia. Kedua, istilah karakter erat kaitannya dengan "personality". Seseorang dapat disebut berkarakter (a person of character) apabila tingkah lakunya sesuai dengan kaidah moral. Perilaku yang terjadi pada manusia dibangun dari nilainilai moral yang ada pada dirinya yang sejalan nilai etika, yang membicarakan perihal baik dan buruk. Sejalan dengan yang dikatakan Lickona bahwa Karakter memiliki tiga bagian yang saling berhubungan, yakni pengetahuan moral, perasaan moral dan perilaku moral. Dimana karakter yang baik terdiri atas, mengetahui hal yang baik, menginginkan hal yang baik, dan melakukan hal yang baik (Lickona:2013). Dengan nilai moral atau karakter tersebutlah, seseorang diyakini dapat mendasari prinsip dan norma yang memandunya untuk bersikap dan berperilaku dalam kehidupannya sebagai pembentuk karakter (Wening: 2012).

Terkait dengan itu, terdapat banyak nilai-nilai kearifan lokal Bugis yang memiliki nilai karakter yang menuntun pada masyarakat Bugis untuk menginternalisasikannya secara individual dan kolektif. Diantara nilai-nilai yang terkandung dalam kearifan lokal Bugis yang berupa sastra dan sejarahnya yakni, ada' tongeng (berkata benar), lempu (jujur), getteng (teguh pendirian), sipakatau (saling menghormati), sipakalebbi (saling memuliakan), assitinajang (kepatutan) dan mappesonae ri Dewata Seuwwae (berserah diri kepada Tuhan). Nilai-nilai kearifan lokal tersebut terdapat secara tersurat dan atau secara tersirat. Dalam pappaseng dan pappangaja, nilai-nilai kearifan lokal Bugis kadang dibahasakan secara 
tersurat, mengetahui maksud dan tujuannya. Setidaknya tujuh nilai-nilai karakter termaktub dalam nilai kearifan lokal Bugis, Baik itu nilai $a d a^{\prime}$ tongeng, lempu, getteng, sipakatau, sipakalebbi, assitinajang dan mappesona ri Dewata Seuwae menjadi nilai-nilai yang dikembangkan dalam Sekolah Bugis ini, sekaligus dijadikan bagian integral dari nilai-nilai yang dituntut untuk dikembangkan dalam pendidikan karakter. Sebagaimana Lockwood mengatakan, bahwa pendidikan karakter merupakan kegiatan yang berbasis lembaga pendidikan dengan tujuan sistematis membentuk perilaku peserta didik (Nucci dan Narvaes: 2014). Sekolah Bugis sebagai lembaga pendidikan untuk membentuk karakter yang bersumber dari niali kearifan lokal Bugis.

Sementara dalam sejarah lokal, pesan-pesan kearifan lokal tersebut kadang tersirat, pemaknaan dari peristiwa yang terjadi menjadi sangat penting untuk kemudian dipahami secara menyeluruh. Karena memang dalam sejarah Bugis Bone yang berbentuk lontara attoriolong, mencatat dan mengkisahkan pemerintahan raja dan peristiwa-peristiwa pada masanya. Peristiwa sejarah yang diungkap memberikan gambaran dinamika pasang surut eksistensi Bone. Peristiwa sejarah Bone yang terjadi tersebut diakibatkan dari faktor-faktor atau penyebab tertentu yang selalu berkaitan dengan pangaddereng (adat istiadat). Asosiasi antara peristiwa sejarah dan nilai-nilai kearifan tersebut akan memberikan makna dan pesan moral untuk merenungi dari "apa sesungguhnya yang terjadi dan kenapa hal tersebut terjadi". Sejarah sebagai pelajaran, belajar dari sejarah, belajar dari pengalaman yang terjadi dan baik pengalaman sendiri dan pengalaman generasi sebelumnya (Hariyono:1995). Sejalan yang dikatakan Slavin, bahwa belajar dari pengalaman akan 
menyebabkan perubahan dalam diri seseorang (Slavin:2009), dan sejarah adalah dokumentasi dari pengalaman manusia.

Hal inilah kemudian yang dilaksanakan di sekolah Bugis ini, pengungkapan pappaseng dan pappangaja (ungkapan nasihat dan petuah) merupakan akumulasi pengalaman masa lampau orang Bugis yang dihadirkan ditengah-tengah masyarakat kekinian. Begitupun dengan peristiwa sejarah lokalnya yang membahas mengenai asal muasal Orang Bugis, terbentuknya Kerajaan Bone dan riwayat raja-raja nya, menjabarkan fenomena-fenomena analisis masa lalu yang dipahami secara maknawi akan memberikan suatu pesan kearifan, ada nilai paseng, bagi para peserta Sekolah Bugis dan masyarakat Bone. Sumber belajar itu mencakup pesan, manusia, media, alat, teknik dan lingkungan (Sanjaya: 2010), maka nilai kearifan lokal Bugis dalam konteks sebagai sumber belajar sejarah lokal dapat dilihat dari dua hal yakni dari segi (konten) dan segi bentuk (wujud). Dari segi isi yakni berupa pesan-pesan leluhur yang diwariskan secara turun temurun dan dari segi bentuk pesan-pesan tersebut yang berwujud, lontara, paper, makalah, buku-buku rujukan, dan atau tulisan-tulisan lainnya. Penyajiannya bak dalam bentuk softcopy maupun hardcopy, oleh Stronge telah menjabarkan bahwa alat sumber belajar itu dapat berupa komputer, LCD, radio, televisi, dan sejenisnya (Stronge: 2007). Hal itulah yang kemudian menjadi sebagai sumber belajar sejarah lokal dilihat dari segi isi (konten) dan wujud serta alat dari sumber belajar itu sendiri.

Sumber belajar adalah pengalaman-pengalaman yang sangat luas, seluas kehidupan yang mecakup segala sesuatu yang dapat dialami dan dapat menimbulkan peristiwa belajar (Edgar:2012) olehnya itu pemilihan 
sumber belajar harus menyediakan pengalaman belajar yang sesuai dengan karakter peserta didik (Holden:2008). Maka secara sederhana, nilai kearifan lokal Bugis telah menjadi sumber belajar bagi masyarakat Bugis melalui sekolah Bugis, karena nilai-nilai pappaseng dan pappangaja yang terkandung dalam sastra dan sejarahnya sebagai identitas yang melekat pada komunitasna, diungkap dan dipelajari sebagai sumber belajar sejarah lokal bagi sekolah Bugis. Sejalan dengan visi sekolah Bugis untuk melestarikan nilai budaya Bugis melalui pemahaman sastra dan sejarahnya. Menghadirkan peristiwa masa lampau ke masa kekinian dengan cara menapak-tilasi peninggalan masa lampau, juga dijadikan bagian dari proses belajar sekolah Bugis melalui kegiatan sekolah lapang seperti mengunjungi makam Raja Latemmasonge di Kabupaten Maros, Makam Raja Bone terbesar, Latenritatta Arung Palakka di Bontoala Kabupaten Gowa, dan terakhir makam raja Bone pertama yang memeluk agama Islam, Latenrirua Sultan Adam di Kabupaten Bantaeng. Menurut Darmawati, kunjungan ke situs bersejarah itu menandakan bahwa pembelajaran kearifan lokal Bugis harus disertai dengan kegiatan lapangan untuk kembali merenungi pemikiran dan perjuangan dari para pendahulu dan mengimplementasikan perjuangannya dalam kehidupan sekarang.

Fungsi belajar sejarah yang terbagi atas empat yakni, fungsi rekreatif (wisata), fungsi edukatif (pendidikan), insfiratif (insfirasi, ilham ), dan instruktif (instruksi, pengajaran). Dari keempat fungsi tersebut tergambarkan bahwa kegiatan sekolah lapang sekolah Bugis ini telah mengimplementasikan dari fungsi belajar sejarah tersebut. Dengan mengunjungi situs bersejarah raja-raja Bone yang memiliki pengaruh 
sejarah pada zamannya, telah menghantarkan peserta sekolah Bugis untuk berekreasi dengan kelampauan, berinteraksi dengan peninggalan sejarah, serta mengambil hikmah dan akan memunculkan dorongan masa lalu untuk melakukan hal yang terbaik di masa kekinian.

\section{KESIMPULAN}

Nilai kearifan lokal Bugis dimaknai sebagai kekayaan intelektual yang diwarisi secara turun temurun dan menjadi ingatan bersama oleh masyarakat Bone. Nilai kearifan lokal yang mencakup sastra dan sejarah Bone yang didalamnya mengandung nilai-nilai budi pekerti yang luhur (pappaseng dan pappangaja) menjadi pedoman dalam bersikap dan berprilaku. Masyarakat Bone melalui sekolah Bugis memahami bahwa, kearifan lokal yang ada harus dilestarikan. Dilestarikan dengan cara mengetahui dan memahami dan juga diterapkan dan dilaksanakan dalam kehidupan sehari-harinya, baik itu dalam diri pribadi, lingkungan keluarga, lingkungan pendidikan, dan lingkungan masyarakat sekitar.

Nilai kearifan lokal Bugis yang mencakup ada' tongeng (berkata benar), lempu (jujur), getteng (teguh pendirian), sipakatau (saling menghormati), sipakalebbi (saling memuliakan), assitinajang (kepatutan), dan mappesonae ri Dewata Seuwwae (berserah diri kepada Tuhan) menjadi bagian dari nilai-nilai utama yang terkandung dalam sastra dan sejarah Bugis. Sebagai sumber belajar sejarah lokal dan pendidikan karakter, maka nilai kearifan lokal Bugis harus digali dan ditelaah kembali, menjabarkan fenomena-fenomena analisis masa lalu yang dipahami secara maknawi akan memberikan suatu pesan kearifan, ada nilai paseng (pesan) bagi para peserta Sekolah Bugis dan masyarakat Bone untuk 
bersikap dan bertindak dalam kehidupan bermasyarakat, berbangsa dan bernegara.

\section{DAFTAR PUSTAKA}

Emzir. ( 2012) Analisis Data Kualitatif. Jakarta: Rajagrafindo

Fajriani, Ulfah. Peranan Kearifan Lokal dalam Pendidikan Karakter. Jurnal Sosio Didaktika: Vol. 1, No.2 Desember 2014, h:128

Hariyono (1995) Mempelajari Sejarah Secara Efektif. Jakarta: Pustaka Jaya

Holden, Jolly T. (2008) An Instructional Media Selection: Guide for Distance Learning (New York: UNCLA

Lickona, Thomas. (2013) Educating For Character ( Mendidik untuk Membentuk Karakter). Jakarta: Bumi Aksara.

Nurnaningsih. Rekonstruksi Falsafah Bugis dalam Pembinaan Karakter; Kajian Naskah Paaseng Toriolo Telumpoccoe. Jurnal Lektur Keagamaan, Vol.13, No.2, Tahun 2015, h:400-402

Nucci, Larry P \& Darcia Narvaes, (2014) Handbook of Moral and Character Education .USA: Routledge

Sugiyono.( 2008) Metode Peneliian Pendidikan Kuantitatif, Kualitatif, dan $R \mathcal{E} D$. Bandung: Alfabeta.

Stronge, Jameshal.( 2007) Qualities of Effective Teacher (Virginia: University of California San Diego,

Sanjaya, Wina (2010) Perencanaan Dan Desain Sistem Belajar Pembelajaran, Jakarta: kencana, Slavin, Robert F .Educational Psychology: Theory and Practice (New Jersey: Pearson Education, 2009.

Wening, Sri. Pembentukan Karakter Bangsa Melalui Pendidikan. Jurnal Pendidikan Karakter, Tahun II, No.1, Februari 2012, h:57 


\section{Sumber wawancara}

Supiati (Peserta Sekolah Bugis), wawancara tanggal 18 februari 2018 Aisyah (Guru SDN 26 Lappabosse) wawancara tanggal 11 Maret 2020 Supriadi, (kepala Dusun Gattareng) pada tanggal 11 maret 2020 